\title{
THE COTTON GROWING INDUSTRY OF NIGERIA
}

THE development of the cotton industry in British West Africa is largely the work of the British Cotton Growing Association; the Association was formed at a General Meeting held at the Manchester Chamber of Commerce on June I2th, I902, the late Sir Alfred Jones being elected President and the capital fixed at $£ 50,000$.

The raison d'etre of the Association was the increasingly heavy demand made from about I895 on the United States crop, the chief source of the world's cotton supply. For this increased consumption American mills were greatly responsible, with the result that in Ig00 there was not enough cotton to supply the demands of the rest of the world.

Lancashire cotton manufacturers perceived that the almost complete dependence on the American crop could only be avoided by growing cotton in other parts of the world, and especially in the British Empire; and necessarily the stability of the industry would be thereby tremendously enhanced. Mr J. Arthur Hutton in a paper read to the Manchester Statistical Society in February I904 stated .-

" We can make up our minds that the U.S. will use more and more of their own cotton every year, with the natural consequence that if other supplies are not forthcoming Europe and the rest of the world will have to go short. The problem to-day before the world is, "Where are these supplies to come from?' and the solution of this problem is the raison d'etre of the B.C.G.A."

Sully's corner in Igo4 gave additional impetus to the movement, for a band of speculators, having cornered the supply (a short crop and active demand being essentially helpful factors), forced up the price of the raw material over 50 per 
cent. On August 27th, I904, His Majesty King Edward VII granted the Association a Royal Charter and the capital was increased to half-a-million sterling.

Naturally the first years of the Association's activities were years of experiment and pioneering; areas suitable for cotton growing had to be discovered; different types of cotton had to be experimented with for the different localities, and above all a competent staff had to be formed and trained. Gradually, as information was collected and results tabulated, the experimental areas were cut down, so that to-day, after some eighteen years of research, the Association can claim to define where cotton will grow profitably, and also where its cultivation will be a failure; for it has investigated almost every potential area in the Empire and even outside it.

Despite its present importance-for it is probably the first textile in the world to-day-two hundred years ago cotton was practically unknown to the civilised nations of the West; Ralph Fitch, who travelled in India about 1583, speaks of the finest cotton cloth being made at "Sinnergan." 1 Small quantities were imported into England in the fifteenth century from the Levant via Genoa merchants, and by 1635 it was a relatively important cotton manufacturing country. At the beginning of the nineteenth century Great Britain consumed some 54 million lbs. of raw cotton, in 1850 the imports had risen to 664 million lbs., and in I9I3-I4 the consumption was well over 2000 million lbs.

It is interesting to note that Lord Palmerston prophesied that the West Coast of Africa would outstrip all other countries in the production of cotton, except the United States. ${ }^{2}$

Although the appearance and growing characteristics of cotton vary greatly, it may be generally described as a bushy plant from three to six feet high, with spreading branches, covered with fruits bearing masses of white wool-like substance -the raw cotton. This wool, or more properly lint, adheres to the seeds of the fruit, there being some 27 to 45 seeds to each fruit, or boll as it is called. The lint is composed of fibres, the length of which varies according to the type of cotton

1 Ralph Fitch. Travels in Indra (1583).

- Watt : The Wild and Cultrvated Cotton Plarts of the World (1907), p. 23. 
concerned; i.e. from half an inch in the semi-wild cottons to very nearly two and a half in the finest grade of Sea Island cotton-the finest of all. Cotton is classified commercially according to its spinning capabilities, and can be broadly divided into four main classes, the finest being Sea Island with a fibre length of from It to 2 inches; Egyptian closely follows with a staple of from I to $I \frac{1}{2}$ inches; best American

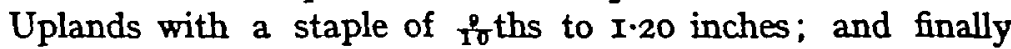
the type forming the bulk of the world's cotton supplyOrdinary American Upland, amounting to 60 per cent. of the total crop and of an average staple of an inch or so.

Cotton is widely distributed, being found wild or cultivated in North and South America, Africa, Asia, India and the Levant, the Pacific Islands, China and Australia. The best and finest cotton for length of staple is Sea Island, grown on a few islands off the southern coast of the United States, also in the British West Indies, and is closely followed by the best Egyptian varieties; the most coarse and short staple is principally Indian, chiefly consumed by Indian mills themselves.

The total world production of cotton is estimated at between 25 and 30 million bales of $500 \mathrm{lbs}$. each; figures for China and large areas of Asia are purely conjectural, and practically all this cotton is consumed by the producing countries. The American, Egyptian and Indian figures are of course carefully worked out and are reliable. For this year the American crop will probably be some $7 \frac{1}{2}$ million bales of $500 \mathrm{lbs}$. each. The various estimates and sources of information regarding the world's cotton production are treated in the Statistical Appendix to Professor Todd's The World's Cotton Crops (I9I5), pp. 393 et seq.

As regards West Africa, probably the earliest historical allusion is by the Portuguese navigator Ramusio, who declares cotton thread and cloth were sold in Nigeria in 1450.1 Certainly the Nigerian cloth industry is very ancient, and Leo Africanus (who explored part of the West Coast of Africa from 1492) repeatedly speaks of the finest cotton coming to the coast towns "from the more interior country of the

1 Ramuszo: Narz. in 1454 of Alozse de ca Da Mosto (ed. 1837). p r89. 
negroes." 1 Which reminds one of Mungo Park's "Pholeys." Very much later Winterbottom ${ }^{2}$ (I803) declares cotton to be as common and neglected as thistles in England, "but is generally of too short a staple, as it is termed in the trade, to be worth exporting." From this time on samples of West African cotton were frequently sent home; as records show a sample from Budagry (Lagos) in I825; from Abeokuta, S. Nigeria, by Dr. Irving, in 1855 ; by Dr. Barter of the Niger Expedition, and even earlier the Abbe Labat describes the cotton he found growing in West Africa in his account of his travels.

A more recent writer says :-

"Cotton grows wild in many parts of West Afnca and is extensively cultivated in some districts, but more for the purpose of supplying local demands than for export. In the latter respect the trade in this article has proved a disappointment: great hopes were entertained at one time that Manchester would be able to draw largely on West Africa for her supplies, but so far the total annual value of the cotton imported into Great Britain from West Africa has pever exceeded a few thousand pounds."

This is very interesting, written as it was in Ig00, in giving us an idea of the work accomplished by the Association in the intervening twenty years. Its operations in British West Africa covered the Gambia, Sierra Leone, the Gold Coast and Nigeria; the result has been that all of these for one reason or another have been gradually eliminated, with the exception of the latter, and cotton growing in West Africa on a large scale and as a great industry depends on Nigeria.

The formation of United Nigeria by the incorporation of the Colony of Lagos and the Protectorates of Southern and Northern Nigeria in I9I2, with a joint area of some 350,000 square miles and a population of about 18 millions, is recent history.

2 Giovan Leone Africanus (Pory transl, 1600).

Winterbottom : Account of Natzoes of Storra Leone (1803), p. 95.

- Nowo. Relation de l'Afraque Occrd (1728), 111 pp 95, 262-69.

- Muckler-Ferryman : British Wost A/ruca (1900) 
The development of the cotton industry by the Association in Nigeria began, one might say, at the same time as effective occupation of the Northern Protectorate was established. It was realised very soon that transport was the greatest factor in any schemes for the development of cotton in Nigeria, and in fact a conditioning factor of its very existence, at least as a great industry. The union of the rivers Niger and Benue at Lokoja roughly divide Nigeria into three vast areas, i. c. northern, eastern and western, the former being roughly twice or more the size of either of the other two. It will be noticed that the Association's operations group themselves under the first and third, leaving the eastern section practically untouched.

As a matter of policy it was decided that the actual growing of the cotton should be a native industry; the plantation system, owing to the cost of labour, its poor results (for the African did not take kindly to farm work as a hired labourer) and the expense of European supervision, was found to be impossibly expensive. Cotton in Africa had to be a "black man's crop." So in Ig04 an agreement was entered into with the Government for the establishment of model farms and experimental stations by the Association, and for the purchase by it of seed cotton at established buying centres; the Association also agreed to erect ginneries and provide travelling experts. The Government on its part paid an annual subsidy to the Association, which undertook to spend at least $\ell^{10,000}$ per annum in the three Colonies of Gambia, Sierra Leone and Nigeria.

Since then many changes have taken place which it would be impossible to treat in this paper; at present the Association has steam ginneries at Ibadan, Oshogbo, and Lafenwa in Southern, and at Zaria, Lokoja and Ibi in Northern Nigeria. It will be noted that all these ginneries are in the western and northern areas of the river division of the country with the exception of Ibi, on the banks of the Benue and the northern border of the eastern area.

The explanation of this is of course Transport-that potent word in Africa! As the railway pushed north so did the operations of the Association. Under existing conditions a 
belt of sixty miles is the limit for the transport of cotton by head-carriage to the railway or river. This means that given fair roads, a steam ginnery can establish buying-centres at a distance of sixty miles; natives will bring in their cotton from thirty to sixty miles to these stations, with the result that a ginnery can expect to tap an area whose radius is some I20 miles or more. With river or rail transport available the area covered is proportionately increased. As a glance at the map will show, the eastern area has so far had practically no means of transport as compared with the other two sections served both by rail and river. Its cotton growing possibilities are immense, and the eastern railway extension which is now under construction will link up Port Harcourt and the main line north of Jebba (crossing the Benue at the Ainsi Bridge), and opening this area as nothing else could.

West of Kano is the Sokoto country, another potential cotton area, as is also the country between Kano and Lake Tchad. This latter was visited in I92I by Mr. J. Percival, the General Manager of the Association in Nigeria, in company with Mr. Lamb, the Director of Agriculture, the object in view being to investigate its cotton possibilities. The limiting factor of transport postpones, however, their devclopment to some future date. In this connection Sir George Watt, ${ }^{1}$ an acknowledged authority, may be quoted -

"Mention has been already made of Lord Palmerston's prophecy that the West Coast of Africa would outstrip all other countries in the production of cotton except the United States. The realisation of that prophecy is still in the future, and is likely to remain so till the great cotton growing tracts have been opened out and facilities for quick and cheap transit provided. Many failures will doubtless frustrate temporarily the endeavours of the pioneers, but if local resources and indigenous stocks are taken in hand and guided forward a full realisation is not only possible but highly likely to be accomplished."

And the immense potentialities of Nigeria are vividly illustrated by the estimate of Professor J. A. Todd, that the possible

1 Watt: Cottons of the World (1907), p. 174. 
cotton crop of the united provinces is about six million bales of 400 lbs. each. ${ }^{1}$

The actual results of the Association's efforts are extremely encouraging. In IgO2 twenty-five bales of cotton were exported from Lagos; a year later the total had risen to 750 ; ten years later, in I9I3, the exports were 16,200 bales." In I9I4 the crop amounted to I4,000 bales, and in IgI5, conditions being very unfavourable, the crop was small, but IgI6 witnessed a crop of 20,000 bales. $^{2}$ In r 920 some 16,000 bales were produced, and it is estimated that the total for I92I will be over 35,000 bales."

The practice of the Association for some years past has been to guarantee to the native farmer a fixed price for his seed cotton each season; this has done much to popularise cotton as a crop and so lead up to the figures just given. ${ }^{\text {b }}$

In IgI4 efforts were made to introduce a new seed called " exotic," which combined the advantages of a heavier yield and a longer and finer staple; eleven bales were produced in I9I4, which rose to 3,380 bales in I920, and in I92I it is estimated that over 8,000 bales will be obtained. Naturally the war period hit the Association hard and it had to carry on as best it could with very depleted stafts, the work being practically at a standstill as far as actual fresh development was concerned.

This improved or " exotic" cotton is worth a premium today of $2 d$. per lb. over Middling American, which fixes the basic price in the world's markets, and so enables the Association to pay a higher price to the farmer, who also gets a heavier yield per acre.

The above figures speak eloquently of the work so far accomplished, the more so as the Association during the same period was actively engaged in cotton cultivation in Nyassaland, Uganda, Mesopotamia, East Africa, and conducting investiga-

1 Todd : The World's Cotton Crops (rg15), p. I70.

- Tbid., p. 200.

- Hutton: Dovelopmons of the Cotton Growing Resources of the Empire (1917).

4. Himbury : Exploration and Development of New Cotton Frolds of the Britzsh Empire (1921), Pp. 6 and 7. 
tions and rendering expert assistance in India, the Soudan, the West Indies, Australia, South Africa, Rhodesia, Fiji and other tropical dependencies.

The Lokoja ginnery is especially well situated for the purpose of gauging the effect of the propaganda in favour of cotton growing on the native farmer. The local purchases at Lokoja itself in I9I5 were I8,755 lbs. seed cotton, and in I920, I69,377 lbs. This ginnery has two buying stations in the Kabba Province, one at Kabba Town and the other at Okeni, both places being some sixty miles from Lokoja, and head carriage is the only means of transport. In IgI5 the Kabba Province purchases were II2,832 lbs., which rose in I92I to over $831,000 \mathrm{lbs}$. The figures for the same district for the years I9I9-20-2I are surprising, the cotton purchased being ro4,532 lbs., 6r6,376 lbs., and $83 \mathrm{r}, 000 \mathrm{lbs}$. respectively. It should be noted that all the cotton purchased by Lokoja ginnery is of the native type and not the improved or " exotic."

The Department of Agriculture, which is in charge of the work of seed distribution and the gradual replacement of the native variety by the improved type (having taken over all this work from the Association some years ago), is extending the area planted with exotic cotton as rapidly as possible.

This extension involves many difficulties; for the native variety and the improved type cannot be allowed to flourish together, as the result would be mutually destructive; and the tenacious, suspicious conservatism of the native farmer must be gradually won over to the new innovation.

The writer believes that Kabba Province, for example, can easily grow (and that within the next few years) five million pounds weight of seed cotton annually. To produce a bale of lint of 400 lbs. weight (the Association's standard bale measuring 80 cubic feet to the ton) requires nearly $I, 500 \mathrm{lbs}$. of seed cotton; so that a five-million-pound crop from Kabba Province would be equivalent to about 3,500 bales, the market value of which at present is about $£ 70,000$. The great difficulty will not be to grow the cotton, but to afford the farmer means to transport it to the ginnery. The limits of head-carriage for any given area are easily ascertained, and unfortunately also as easily attained. It is probable that as things are at present 
the maximum amount of cotton that can be transported to Lokoja is under two million lbs.

It would seem future development, at least as far as any great increase in bale output is concerned, depends almost entirely on the progressive development of transport facilities. It may be confidently expected that no efforts will be spared and that considerable success will be obtained in improving the quality of the cotton grown in areas already exploited, in addition to educating the native cultivator in better methods of farming and handling the crop. These advances do not depend on either river or rail, and will do much to provide the firm foundation so necessary if the ever-increasing possibilities of cotton cultivation presaged by the extension of transport facilities in Nigeria are to be ever adequately realised.

Everything would indicate, therefore, that in Nigeria cotton cultivation has come to stay and has proved a success. That much requires to be done is of course a truism, but nevertheless, Mr. Hutton's statement before the Manchester Athenæum-

"That there is therefore more than a probability that we may shortly see an annual crop of at least 100,000 bales in the immediate future, with the possibility some day of the millions of bales which Lancashire so urgently requires,"

may be much nearer to realisation than even the most sanguine of us expected.

E. DE C. DUGGaN. 